\title{
Response of Soil Respiration to Grazing in an Alpine Meadow at Three Elevations in Tibet
}

\author{
Gang Fu, ${ }^{1}$ Xianzhou Zhang, ${ }^{1}$ Chengqun Yu, ${ }^{1}$ Peili Shi, ${ }^{1}$ Yuting Zhou, ${ }^{2}$ Yunlong Li, ${ }^{1,3}$ \\ Pengwan Yang, ${ }^{1,3}$ and Zhenxi Shen ${ }^{1}$ \\ ${ }^{1}$ Chinese Academy of Sciences, Institute of Geographic Sciences and Natural Resources Research, Key Laboratory of Ecosystem Network \\ Observation and Modeling, Lhasa Plateau Ecosystem Research Station, Beijing 100101, China \\ ${ }^{2}$ Department of Microbiology and Plant Botany, Center for Spatial Analysis, University of Oklahoma, Norman, OK 73019, USA \\ ${ }^{3}$ College of Resources and Environment, University of Chinese Academy of Sciences, Beijing 100049, China
}

Correspondence should be addressed to Zhenxi Shen; shenzx@igsnrr.ac.cn

Received 8 October 2013; Accepted 27 February 2014; Published 24 March 2014

Academic Editors: J. Aherne, F. Bastida, and K. Wang

Copyright (C) 2014 Gang Fu et al. This is an open access article distributed under the Creative Commons Attribution License, which permits unrestricted use, distribution, and reproduction in any medium, provided the original work is properly cited.

\begin{abstract}
Alpine meadows are one major type of pastureland on the Tibetan Plateau. However, few studies have evaluated the response of soil respiration $\left(R_{s}\right)$ to grazing along an elevation gradient in an alpine meadow on the Tibetan Plateau. Here three fenced enclosures were established in an alpine meadow at three elevations (i.e., $4313 \mathrm{~m}, 4513 \mathrm{~m}$, and $4693 \mathrm{~m}$ ) in July 2008 . We measured $R_{s}$ inside and outside the three fenced enclosures in July-September, 2010-2011. Topsoil $(0-20 \mathrm{~cm})$ samples were gathered in July, August, and September, 2011. There were no significant differences for $R_{s}$, dissolved organic C (DOC), and belowground root biomass (BGB) between the grazed and ungrazed soils. Soil respiration was positively correlated with soil organic C (SOC), microbial biomass (MBC), DOC, and BGB. In addition, both $R_{s}$ and BGB increased with total N (TN), the ratio of SOC to TN, ammonium N $\left(\mathrm{NH}_{4}{ }^{+}-\right.$ $\mathrm{N}$ ), and the ratio of $\mathrm{NH}_{4}{ }^{+}-\mathrm{N}$ to nitrate $\mathrm{N}$. Our findings suggested that the negligible response of $R_{s}$ to grazing could be directly attributed to that of respiration substrate and that soil $\mathrm{N}$ may indirectly affect $R_{s}$ by its effect on $\mathrm{BGB}$.
\end{abstract}

\section{Introduction}

Soil respiration $\left(R_{s}\right)$ is an important flux in the C cycle [1-3]. Raich and Schlesinger [1] indicated that $R_{s}$ is the second in magnitude to gross primary production but equivalent to or even greater than net primary production. Root and microbial respiration are the two most important components of $R_{s}$; thus the factors which affect root growth and microbial activity could all influence $R_{s}$ [4-6]. Water availability and temperature are the two most important abiotic factors controlling $R_{s}$ at various spatial and temporal scales $[7,8]$. The positive relationship between $R_{s}$ and temperature could be weakened or masked by other factors (e.g., respiration substrate) $[9,10]$. Previous studies have shown that $R_{s}$ increases with respiration substrate, including labile $\mathrm{C}$ (e.g., microbial biomass $\mathrm{C}, \mathrm{MBC}$; dissolved organic $\mathrm{C}, \mathrm{DOC}$ ) and belowground root biomass (BGB) [5, 10-12]. Soil $\mathrm{N}$ also affect $R_{s}$ by influencing plant growth and microbial activity $[6,13]$.
Grazing is a major type of land use in grasslands and previous studies have shown inconsistent results on the response of $R_{s}$ to grazing $[14,15]$. Many studies have indicated that grazing significantly decreased $R_{s}[14,16,17]$, whereas other studies have shown quite the contrary result $[18,19]$. The responses of soil C and $\mathrm{N}$ (e.g., MBC, DOC, microbial biomass $\mathrm{N}$, and dissolved organic $\mathrm{N}$ ) to grazing differ among previous studies [20-23]. There are also inconsistent results on the response of BGB to grazing $[15,24]$. The response of $R_{s}$ to grazing is complex and may be dependent on the responses of respiration substrate [25] and soil $\mathrm{N}$.

Alpine meadows are a major type of pastureland on the Tibetan Plateau $[14,22]$ and store $4.68 \mathrm{Pg}$ soil organic C (SOC) with density of $9.05 \mathrm{~kg} \mathrm{~m}^{-2}$ at depth of 0-100 $\mathrm{cm} \mathrm{[26].}$ Few studies have evaluated the response of $R_{s}$ to grazing in an alpine meadow along an elevation gradient, although pasture for domestic sheep and yak is a common land use type on the Tibetan Plateau [22]. Here, we investigated the grazing effect 
on $R_{s}$ in an alpine meadow at three elevations (i.e., $4313 \mathrm{~m}$, $4513 \mathrm{~m}$, and $4693 \mathrm{~m}$ ) on the Northern Tibetan Plateau.

The main objectives of this study were to examine (1) the effect of grazing on $R_{s}$, soil $\mathrm{C}$, and $\mathrm{N}$ and (2) the relationships between $R_{s}$ and respiration substrate (soil organic C, MBC, DOC, and BGB) and soil $\mathrm{N}$ (total $\mathrm{N}$, microbial biomass $\mathrm{N}$, dissolved organic $\mathrm{N}$, ammonium $\mathrm{N}$, and nitrate $\mathrm{N}$ ) along an elevation gradient in an alpine meadow in Tibet.

\section{Materials and Methods}

2.1. Study Area. The study area $\left(30^{\circ} 30^{\prime}-30^{\circ} 32^{\prime} \mathrm{N}\right.$ and $91^{\circ} 03^{\prime}-$ $\left.91^{\circ} 04^{\prime} \mathrm{E}\right)$ was located at the Damxung Grassland Observation Station, Tibetan Autonomous Region in China. Annual mean solar radiation was $7527.6 \mathrm{MJ} \mathrm{m}^{-2}$ and sunlight was $2880.9 \mathrm{~h}$ [12]. Annual average precipitation was around 476.8 $\mathrm{mm}$ and annual potential evapotranspiration was about $1725.7 \mathrm{~mm}$ [27]. Annual mean air temperature was $1.3^{\circ} \mathrm{C}$ [12]. The soil was classified as a shallow sandy loam ( $0.5-0.7 \mathrm{~m}$ ), with organic matter of $0.3-11.2 \%$, total $\mathrm{N}$ of $0.03-0.49 \%$, and $\mathrm{pH}$ of $6.0-6.7$ [22]. The vegetation surrounding the study site was Kobresia-dominated alpine meadow [28]. Roots are mainly concentrated in the topsoil layer $(0-20 \mathrm{~cm})$ [29].

Based on meteorological observations from 1963 to 2012 at the Damxung Station ( $4288 \mathrm{~m}$, approximately $4 \mathrm{~km}$ from our study site), there was no significant change for annual precipitation, while annual mean air temperature increased at a rate of $0.04^{\circ} \mathrm{Ca}^{-1}[12]$.

2.2. Experimental Design. Three sites (about $20 \mathrm{~m} \times 20 \mathrm{~m}$ for each) were fenced in an alpine meadow on a southfacing slope on the Nyainqentanglha Mountains along an elevation gradient (i.e., $4313 \mathrm{~m}, 4513 \mathrm{~m}$, and $4693 \mathrm{~m}$ ) in July 2008. Before enclosure, the site at elevation $4313 \mathrm{~m}$ was winter pasture, while the other two sites were summer pasture [22]. A more detailed description of the experimental design can be found in Fu et al. [22].

Soil temperature $\left(T_{s}\right)$ at a depth of $5 \mathrm{~cm}$, soil water content $(\mathrm{SWC})$ at a depth of $10 \mathrm{~cm}$, and air temperature and relative humidity at a height of $15 \mathrm{~cm}$ were continuously monitored using data loggers (HOBO weather station, Onset Computer Corporation, USA) at each elevation [22]. Both air temperature and $T_{s}$ increased with decreasing elevation [22].

2.3. Measurement of $R_{s}$. Soil respiration was measured using a soil $\mathrm{CO}_{2}$ flux system (LI-8100, LI-COR Biosciences, Lincoln, NE, USA) [6, 30] during the period from July to September in 2010 and 2011 (Figure 1). Soil respirationat 9:0011:00 am was close to daily average $R_{s}[6,31]$; thus $R_{s}$ was measured between 9:00 and 11:00 (local time) in this study. Four polyvinyl chloride (PVC) collars $(20 \mathrm{~cm}$ in diameter and $5 \mathrm{~cm}$ in height) were inserted into the soil to depths of about $2-3 \mathrm{~cm}$ on each measuring date. All the PVC collars were installed and the aboveground biomass was removed at least $12 \mathrm{~h}$ before $R_{s}$ measurement in order to reduce disturbance $[6,12]$. The opaque survey chamber was manually mounted
TABLE 1: Repeated-measures analysis of variance for the main and interactive effects of grazing $(G)$ and measuring date (D) on soil respiration $\left(R_{s}, \mu \mathrm{mol} \mathrm{CO} \mathrm{m}^{-2} \mathrm{~s}^{-1}\right)$ in an alpine meadow at three elevations (i.e., $4313 \mathrm{~m}, 4513 \mathrm{~m}$, and $4693 \mathrm{~m}$ ) on the Tibetan Plateau $(n=4)$.

\begin{tabular}{lcccccc}
\hline \multirow{2}{*}{ Model } & \multicolumn{2}{c}{$4313 \mathrm{~m}$} & \multicolumn{2}{c}{$4513 \mathrm{~m}$} & \multicolumn{2}{c}{$4693 \mathrm{~m}$} \\
& $F$ & $P$ & $F$ & $P$ & $F$ & $P$ \\
\hline $\mathrm{G}$ & 5.94 & 0.051 & 2.39 & 0.173 & 1.22 & 0.311 \\
$\mathrm{D}$ & $\mathbf{3 4 . 1 2}$ & $<0.001$ & $\mathbf{2 9 . 0 8}$ & $<0.001$ & $\mathbf{1 0 . 0 2}$ & $<0.001$ \\
$\mathrm{G} \times \mathrm{D}$ & 1.60 & 0.249 & 1.39 & 0.277 & 0.31 & 0.837 \\
\hline
\end{tabular}

on PVC collars for $R_{s}$ measurements [30]. One cycle was performed on each measuring date.

2.4. Soil Sampling and Analysis. Topsoil samples $(0-20 \mathrm{~cm}$ depth) inside and outside the three fenced enclosures were collected (using a soil auger of $3.0 \mathrm{~cm}$ in diameter) on July 7 , August 9, and September 10, 2011 [22]. Five soil subsamples were randomly sampled and composited into one soil sample for each of the four replicates. The composited soil samples were stored in an icebox and transferred to laboratory. We sieved soil samples (with a sieve of $1 \mathrm{~mm}$ diameter) and picked up any visible roots from the sieved soil. Subsamples of the sieved soil were used to measure $\mathrm{NO}_{3}{ }^{-}-\mathrm{N}, \mathrm{NH}_{4}{ }^{+}-\mathrm{N}, \mathrm{DOC}$, and DON. All the roots in the soil samples were washed, dried at $65^{\circ} \mathrm{C}$ for $48 \mathrm{~h}$, and weighed.

We extracted $20 \mathrm{~g}$ fresh soil samples using $100 \mathrm{~mL} \mathrm{~K}_{2} \mathrm{SO}_{4}$. The $\mathrm{K}_{2} \mathrm{SO}_{4}$ extracts were filtered through $0.45 \mu \mathrm{m}$ filter membrane and then soil available $\mathrm{N}\left(\mathrm{SAN}, \mathrm{NO}_{3}{ }^{-} \mathrm{N}\right.$, and $\mathrm{NH}_{4}{ }^{+}$$\mathrm{N})$ in the extracts were analyzed on a LACHAT Quickchem Automated Ion Analyzer.

The methods of Jones and Willett [32] were used to determine DOC and dissolved total N (DTN). Briefly, we extracted $20 \mathrm{~g}$ fresh soil samples using $100 \mathrm{~mL}$ ultrapure water and filtered the extracts through $0.45 \mu \mathrm{m}$ filter membrane. We analyzed the extractable soil organic $\mathrm{C}$ and total $\mathrm{N}$ in the ultrapure water extracts using a Liqui TOC II elementar analyzer (Elementar Liqui TOC, Elementar Co., Hanau, Germany) and a UV-1700 PharmaSpec visible spectrophotometer $(220 \mathrm{~nm}$ and $275 \mathrm{~nm})$, respectively. Dissolved inorganic $\mathrm{N}$ (DIN) concentrations in the ultrapure water extracts were also determined on a LACHAT Quickchem Automated Ion Analyzer. Then, DON was calculated as the difference between DTN and DIN. Soil organic C, TN, MBC, and MBN data were obtained from Fu et al. [22].

2.5. Statistical Analysis. Repeated-measures analysis of variance (ANOVA) was used to estimate the main and interactive effects of measuring date and grazing on $R_{s}$ for each site (Table 1). Repeated-measures ANOVA was used to estimate the main and interactive effects of sampling date and grazing on DOC, DON, DOC/DON ratio, $\mathrm{NO}_{3}{ }^{-}-\mathrm{N}$, $\mathrm{NH}_{4}{ }^{+}-\mathrm{N}, \mathrm{NH}_{4}{ }^{+}-\mathrm{N} / \mathrm{NO}_{3}{ }^{-}-\mathrm{N}$ ratio, $\mathrm{SAN}$, and BGB (Table 2). Student-Newman-Keuls multiple comparisons were performed among the three sites. Linear relationships of $R_{s}$ with SOC, TN, SOC/TN ratio, MBC, MBN, DOC, DON, $\mathrm{NH}_{4}{ }^{+}$ $\mathrm{N}, \mathrm{SAN}, \mathrm{NH}_{4}{ }^{+}-\mathrm{N} / \mathrm{NO}_{3}{ }^{-}-\mathrm{N}$ ratio, and $\mathrm{BGB}$ were conducted, 
TABLE 2: Repeated-measures analysis of variance for the main and interactive effects of grazing $(\mathrm{G})$ and sampling date (D) on dissolved organic $\mathrm{C}\left(\mathrm{DOC}, \mathrm{mg} \mathrm{kg}^{-1}\right)$ and $\mathrm{N}\left(\mathrm{DON}, \mathrm{mg} \mathrm{kg}^{-1}\right)$, the ratio of DOC and DON (DOC/DON ratio), nitrate $\mathrm{N}\left(\mathrm{NO}_{3}^{-}-\mathrm{N}^{-} \mathrm{mg} \mathrm{kg}^{-1}\right)$, ammonium $\mathrm{N}\left(\mathrm{NH}_{4}{ }^{+}-\mathrm{N}, \mathrm{mg} \mathrm{kg}^{-1}\right)$, the ratio of $\mathrm{NH}_{4}{ }^{+}-\mathrm{N}$ and $\mathrm{NO}_{3}{ }^{-}-\mathrm{N}\left(\mathrm{NH}_{4}{ }^{+}-\mathrm{N} / \mathrm{NO}_{3}{ }^{-}-\mathrm{N}\right.$ ratio), soil available $\mathrm{N}$ (SAN, mg kg $\left.{ }^{-1}\right)$, and belowground root biomass (BGB, $\mathrm{kg} \mathrm{m}^{-2}$ ) in an alpine meadow at three elevations (i.e., $4313 \mathrm{~m}, 4513 \mathrm{~m}$, and $4693 \mathrm{~m}$ ) on the Tibetan Plateau ( $n=4$ ).

\begin{tabular}{|c|c|c|c|c|c|c|c|c|c|}
\hline Elevation & Model & DOC & DON & DOC/DON ratio & $\mathrm{NO}_{3}{ }^{-}-\mathrm{N}$ & $\mathrm{NH}_{4}^{+}-\mathrm{N}$ & $\mathrm{NH}_{4}{ }^{+}-\mathrm{N} / \mathrm{NO}_{3}{ }^{-}-\mathrm{N}$ ratio & SAN & BGB \\
\hline \multirow{3}{*}{$4313 \mathrm{~m}$} & G & 0.77 & 1.65 & 0.46 & $27.10^{* *}$ & $26.05^{* *}$ & 1.05 & $95.61^{* * *}$ & 0.00 \\
\hline & $\mathrm{D}$ & $26.25^{* * *}$ & $4.80^{*}$ & $5.00^{*}$ & $57.55^{* * *}$ & $10.47^{* *}$ & $8.95^{* *}$ & $29.95^{* * *}$ & 2.79 \\
\hline & $\mathrm{G} \times \mathrm{D}$ & 2.64 & 1.46 & 0.29 & $11.02^{* *}$ & 3.00 & 2.16 & $7.13^{*}$ & 1.45 \\
\hline \multirow{3}{*}{$4513 \mathrm{~m}$} & $\mathrm{G}$ & 0.00 & 2.23 & 5.51 & $7.29^{*}$ & $13.99^{* *}$ & 0.04 & $16.50^{* *}$ & 1.52 \\
\hline & $\mathrm{D}$ & $35.53^{* * *}$ & $4.38^{*}$ & 0.40 & $51.70^{* * *}$ & $29.87^{* * *}$ & $12.29^{* * *}$ & $57.31^{* * *}$ & 2.74 \\
\hline & $\mathrm{G} \times \mathrm{D}$ & 3.15 & 3.81 & 3.49 & 1.85 & 2.05 & 0.51 & 3.07 & 0.98 \\
\hline \multirow{3}{*}{$4693 \mathrm{~m}$} & G & 0.00 & 0.16 & 0.12 & 0.82 & 0.27 & 0.08 & 0.65 & 0.64 \\
\hline & $\mathrm{D}$ & 1.33 & 3.67 & 3.03 & $9.24^{* *}$ & $15.27^{* * *}$ & 0.94 & $15.78^{* * *}$ & 3.85 \\
\hline & $\mathrm{G} \times \mathrm{D}$ & 3.41 & 1.24 & 0.04 & 1.79 & $6.95^{* *}$ & 0.30 & $5.67^{*}$ & 0.95 \\
\hline
\end{tabular}

${ }^{*},{ }^{* *}$, and ${ }^{* * *}$ means $P<0.05, P<0.01$, and $P<0.001$, respectively.

respectively. All the statistical tests were performed using the SPSS software (version 16.0; SPSS Inc., Chicago, IL).

\section{Results}

At elevation $4313 \mathrm{~m}, \mathrm{NO}_{3}^{-}-\mathrm{N}, \mathrm{NH}_{4}{ }^{+}-\mathrm{N}$, and $\mathrm{SAN}$ under grazing were $31.78 \%\left(1.95 \mathrm{mg} \mathrm{kg}^{-1}\right), 39.14 \%\left(2.34 \mathrm{mg} \mathrm{kg}^{-1}\right)$, and $35.41 \%\left(4.29 \mathrm{mg} \mathrm{kg}^{-1}\right)$ lower compared with ungrazed soils across all the three sampling dates (Figure 2 and Table 2). Similarly, at elevation $4513 \mathrm{~m}, \mathrm{NO}_{3}{ }^{-}-\mathrm{N}, \mathrm{NH}_{4}{ }^{+}-\mathrm{N}$, and SAN under grazing were $22.00 \%\left(1.41 \mathrm{mg} \mathrm{kg}^{-1}\right), 23.60 \%$ $\left(1.33 \mathrm{mg} \mathrm{kg}^{-1}\right)$, and $22.75 \%\left(2.75 \mathrm{mg} \mathrm{kg}^{-1}\right)$ lower than that of ungrazed soils (Figure 2 and Table 2). In contrast, there were no significant differences of $\mathrm{NO}_{3}{ }^{-}-\mathrm{N}, \mathrm{NH}_{4}{ }^{+}-\mathrm{N}$, and SAN between ungrazed and grazed soils at elevation $4693 \mathrm{~m}$ (Figure 2 and Table 2).

In addition, grazing had no significant effects on $\mathrm{NH}_{4}{ }^{+}$$\mathrm{N} / \mathrm{NO}_{3}{ }^{-}-\mathrm{N}$ ratio, DOC, DON, DOC/DON ratio, and BGB for the three alpine meadow sites (Figure 2 and Table 2). Regardless of grazing, $\mathrm{NO}_{3}{ }^{-}-\mathrm{N}, \mathrm{NH}_{4}{ }^{+}-\mathrm{N}, \mathrm{NH}_{4}{ }^{+}-\mathrm{N} / \mathrm{NO}_{3}{ }^{-}-$ $\mathrm{N}$ ratio, SAN, DOC, DON, DOC/DON ratio, and BGB all showed similar seasonal dynamics among the three elevations (Figure 2).

No significant differences of DOC, $\mathrm{NH}_{4}{ }^{+}-\mathrm{N}$, and $\mathrm{NH}_{4}{ }^{+}$$\mathrm{N} / \mathrm{NO}_{3}{ }^{-}-\mathrm{N}$ ratio were found between elevations $4313 \mathrm{~m}$ and $4513 \mathrm{~m}$, whereas they were significantly lower compared with elevation $4693 \mathrm{~m}$ whether or not grazing was present. Average DOC at elevations $4313 \mathrm{~m}$ and $4513 \mathrm{~m}$ across all the three sampling dates was $33.01 \%$ and $29.31 \%$ lower than that of elevation $4693 \mathrm{~m}$, respectively, irrespective of grazing $(P<$ 0.05 ). Average $\mathrm{NH}_{4}{ }^{+}-\mathrm{N}$ at elevations $4313 \mathrm{~m}$ and $4513 \mathrm{~m}$ was $68.40 \%$ and $67.23 \%$ lower compared with elevation $4693 \mathrm{~m}$, respectively $(P<0.05)$. Average $\mathrm{NH}_{4}{ }^{+}-\mathrm{N} / \mathrm{NO}_{3}{ }^{-}-\mathrm{N}$ ratio at elevations $4313 \mathrm{~m}$ and $4513 \mathrm{~m}$ was $66.76 \%$ and $70.52 \%$ lower compared with elevation $4693 \mathrm{~m}$, respectively $(P<0.05)$.

Average DON at elevations $4313 \mathrm{~m}$ and $4513 \mathrm{~m}$ across all the three sampling dates was $50.78 \%$ and $33.84 \%$ lower than that of elevation $4693 \mathrm{~m}$ under grazing, respectively $(P<$ $0.05)$, whereas there was no significant difference between elevations $4313 \mathrm{~m}$ and $4513 \mathrm{~m}$. There were no significant differences of average DON among the three sites when grazing was absent.

Average SAN at elevations $4313 \mathrm{~m}$ and $4513 \mathrm{~m}$ across all the three sampling dates was $38.69 \%$ and $38.88 \%$ lower than that of elevation $4693 \mathrm{~m}$ when grazing was absent, respectively $(P<0.05)$, while no significant difference between the two lower elevations was found. By contrast, average SAN increased with increasing elevation under grazing $(F=$ 375.30, $P<0.001)$.

No significant differences of DOC/DON ratio and $\mathrm{NO}_{3}{ }^{-}$$\mathrm{N}$ were found among the three sites whether or not grazing was present.

The main effect of grazing and its interactive effect with measuring date on $R_{s}$ were not significant for each alpine meadow site (Figure 1 and Table 1). Grazing only tended to decrease the average $R_{s}$ across all the measuring dates by $14.02 \%\left(0.25 \mu \mathrm{mol} \mathrm{CO} \mathrm{m}^{-2} \mathrm{~s}^{-1}\right), 4.70 \%(0.11 \mu \mathrm{mol}$ $\left.\mathrm{CO}_{2} \mathrm{~m}^{-2} \mathrm{~s}^{-1}\right)$, and $-4.07 \%\left(-0.15 \mu \mathrm{mol} \mathrm{CO} \mathrm{CO}^{-2} \mathrm{~s}^{-1}\right)$ at elevations $4313 \mathrm{~m}, 4513 \mathrm{~m}$, and $4693 \mathrm{~m}$, respectively. In contrast, there was significant seasonal variation for $R_{s}$ (Figure 1 and Table 1). Regardless of grazing, $R_{s}$ showed similar seasonal dynamics among the three elevations (Figure 1).

There were significant elevation effects on $R_{s}(F=147.94$, $P<0.001$ for ungrazed condition; $F=227.25, P<0.001$ for grazed condition) and BGB $(F=315.20, P<0.001$ for ungrazed condition; $F=58.81, P<0.001$ for grazed condition) across all the measuring dates.

Belowground biomass was positively related to $\mathrm{TN}$, $\mathrm{NH}_{4}{ }^{+}-\mathrm{N}, \mathrm{SAN}, \mathrm{SOC} / \mathrm{TN}$ ratio, and $\mathrm{NH}_{4}{ }^{+}-\mathrm{N} / \mathrm{NO}_{3}{ }^{-} \mathrm{-N}$ ratio, respectively (Figure 3), but not to $\mathrm{NO}_{3}{ }^{-}-\mathrm{N}$ (data not shown).

$R_{s}$ was positively correlated with SOC, TN, SOC/TN ratio, MBC, MBN, DOC, DON, $\mathrm{NH}_{4}{ }^{+}-\mathrm{N}, \mathrm{SAN}, \mathrm{NH}_{4}{ }^{+}-\mathrm{N} / \mathrm{NO}_{3}{ }^{-}{ }^{-} \mathrm{N}$ ratio, and $\mathrm{BGB}$, respectively (Figure 4 ). However, $R_{s}$ was not linearly correlated with $\mathrm{DOC} / \mathrm{DON}$ ratio, $\mathrm{MBC} / \mathrm{MBN}$ ratio, and $\mathrm{NO}_{3}{ }^{-}-\mathrm{N}$ (data not shown).

\section{Discussion}

Previous studies indicated that grazer urine and dung stimulated soil microbial activity and accelerated nutrient cycling 


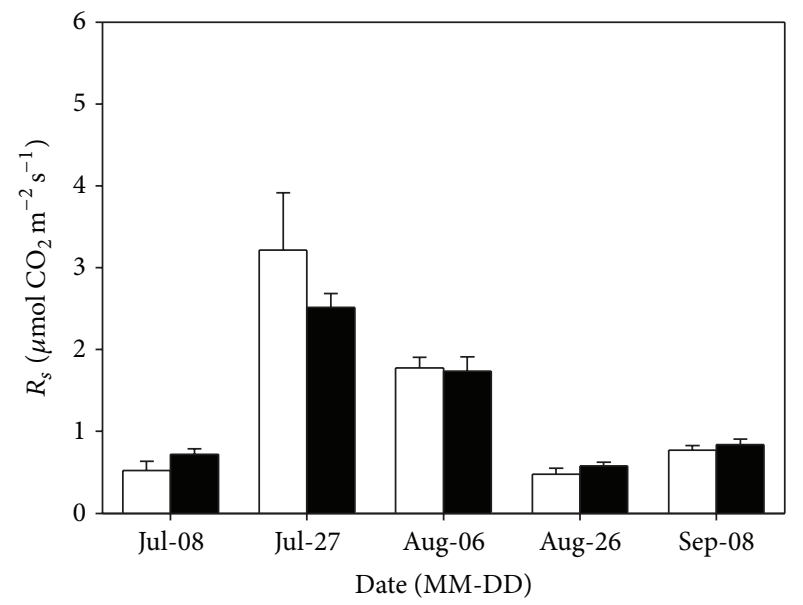

(a)

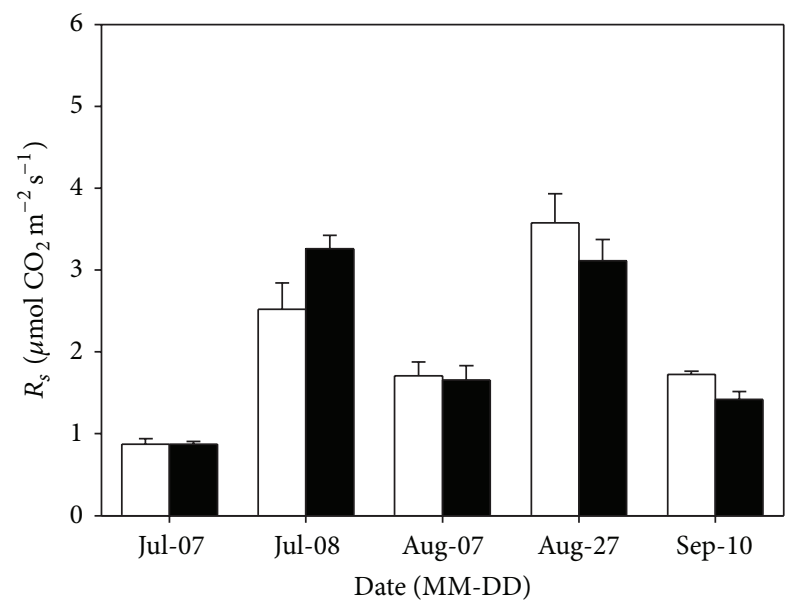

(c)

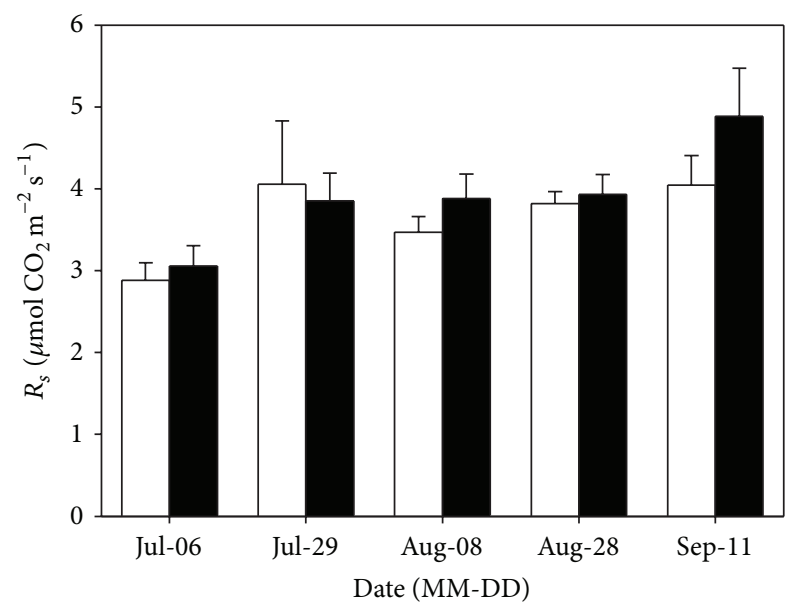

$\square$ Ungrazing

Grazing

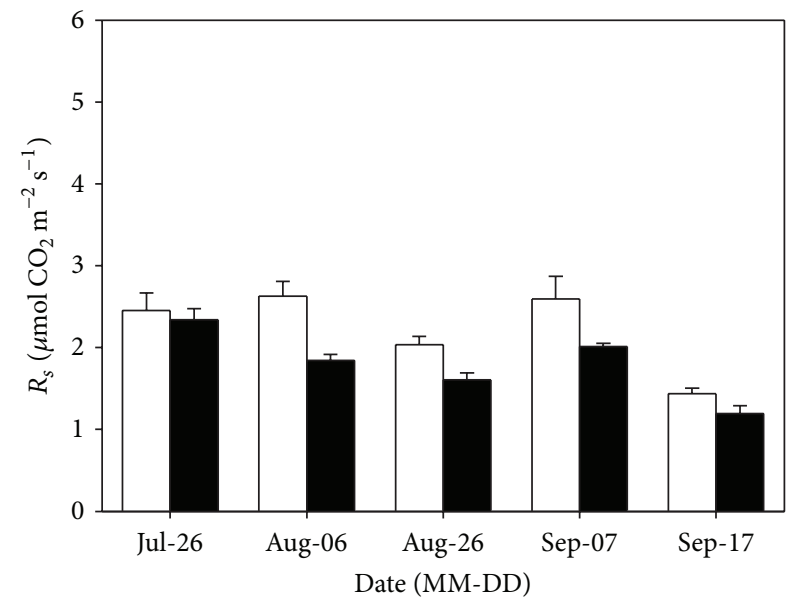

(b)

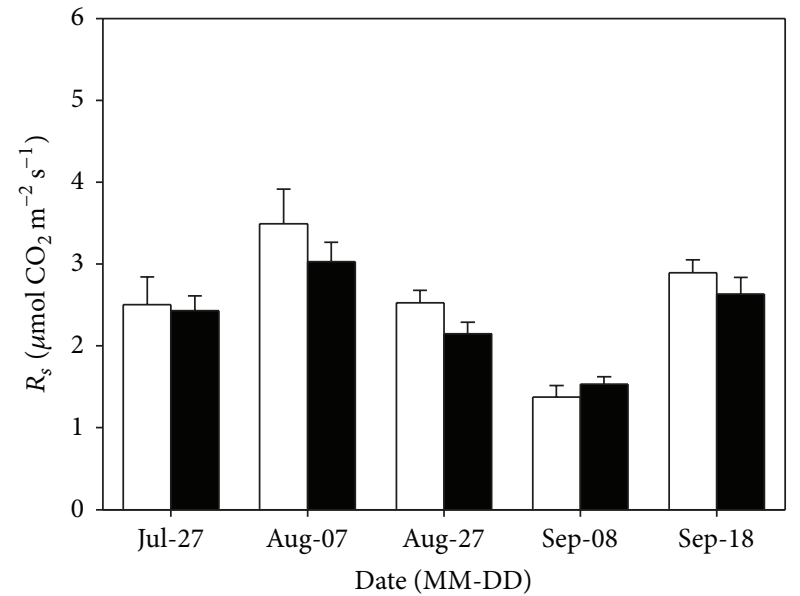

(d)

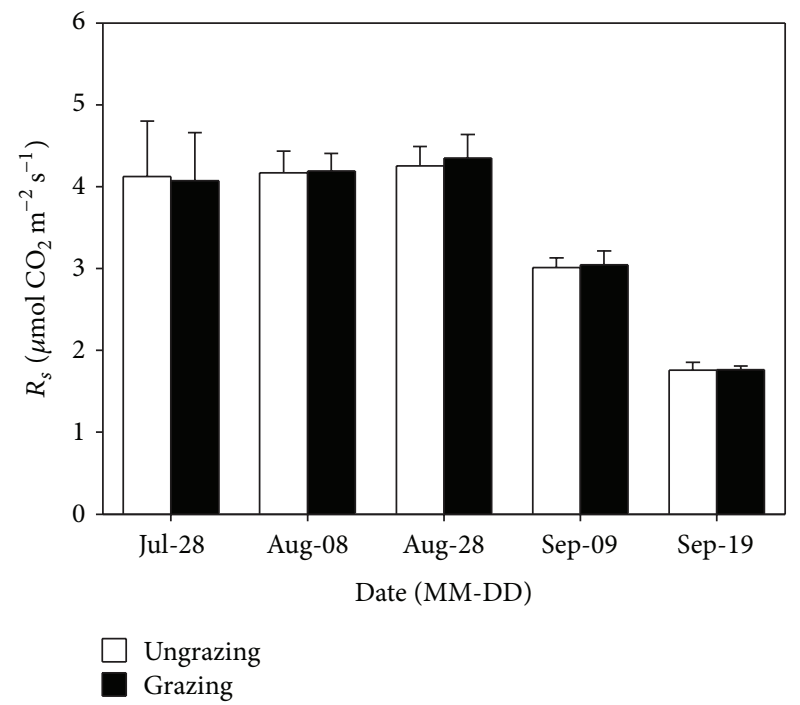

(f)

FIGURE 1: Effects of grazing on soil respiration $\left(R_{s}, \mu \mathrm{mol} \mathrm{CO} \mathrm{m}^{-2} \mathrm{~s}^{-1}\right)$ in an alpine meadow located at elevations of $4313 \mathrm{~m}(\mathrm{a}, \mathrm{b}), 4513 \mathrm{~m}(\mathrm{c}$, d), and $4693 \mathrm{~m}$ (e, f) on the Tibetan Plateau in 2010 (a, c, and e) and 2011 (b, d, and f), respectively. Error bars represent standard error $(n=4)$. 


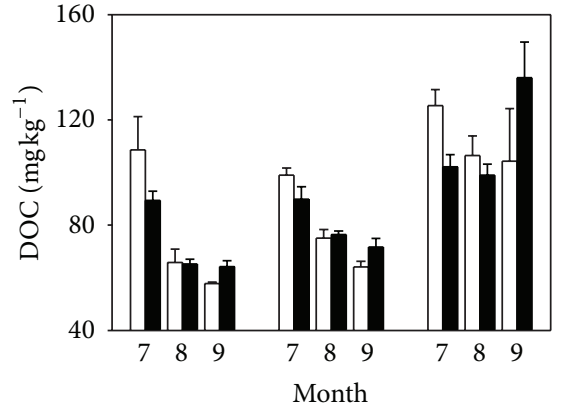

(a)

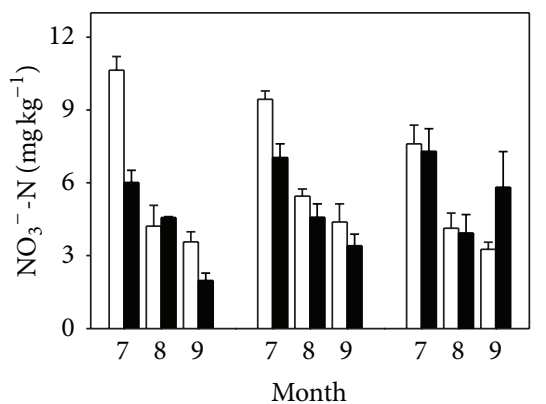

(d)

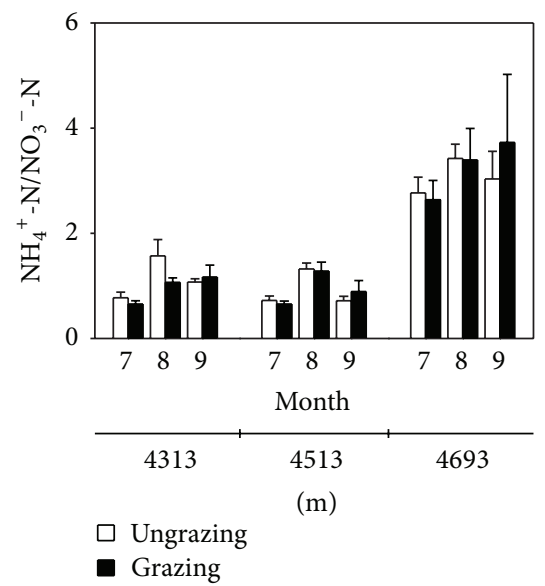

(g)

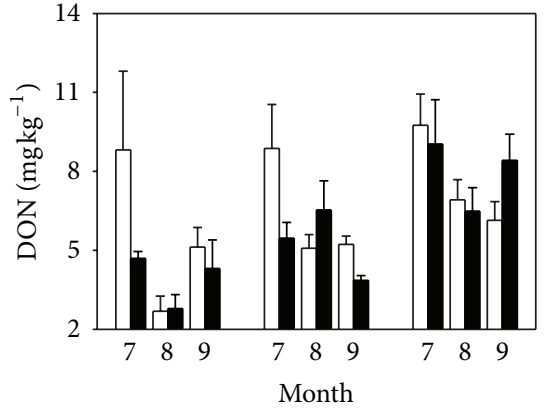

(b)

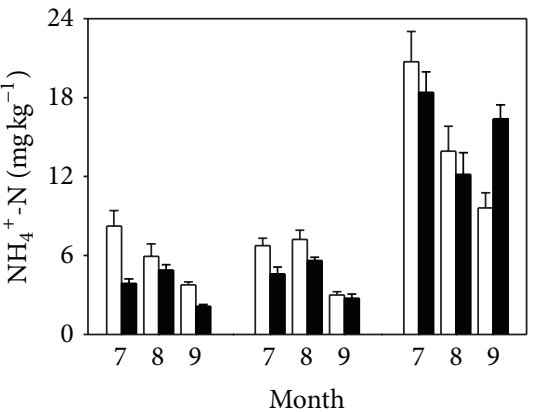

(e)

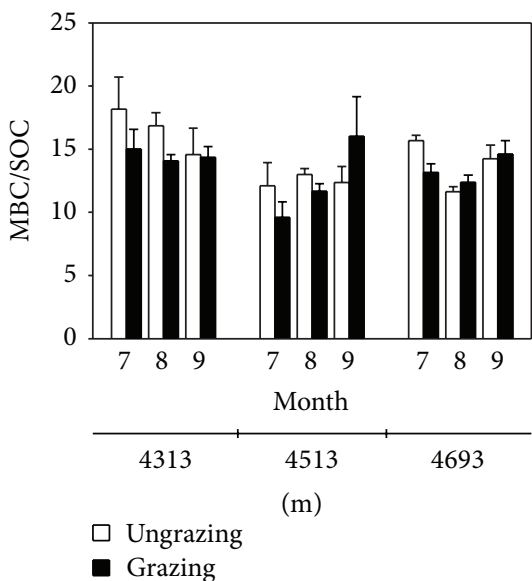

(h)

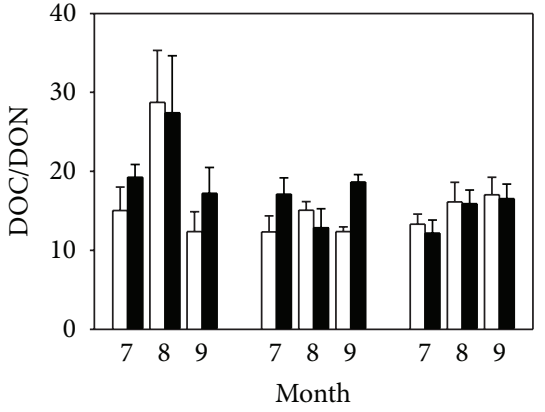

(c)

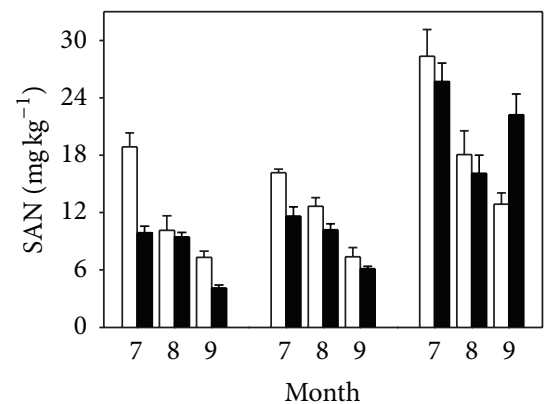

(f)

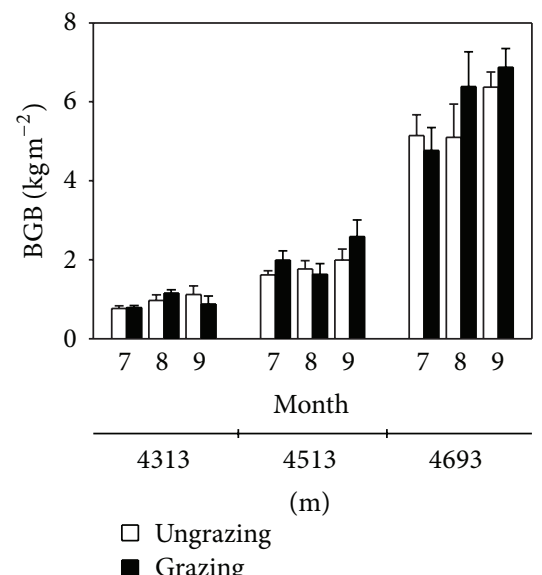

(i)

FIGURE 2: Effects of grazing on dissolved organic $\mathrm{C}$ (DOC, $\mathrm{mg} \mathrm{kg}^{-1}$ ), dissolved organic $\mathrm{N}$ (DON, $\mathrm{mg} \mathrm{kg}^{-1}$ ), the ratio of DOC and DON (DOC/DON ratio), nitrate $\mathrm{N}\left(\mathrm{NO}_{3}^{-}-\mathrm{N}, \mathrm{mg} \mathrm{kg}^{-1}\right)$, ammonium $\mathrm{N}\left(\mathrm{NH}_{4}^{+}-\mathrm{N}, \mathrm{mg} \mathrm{kg}^{-1}\right)$, soil available $\mathrm{N}\left(\mathrm{SAN}, \mathrm{mg} \mathrm{kg}^{-1}\right)$, the ratio of NH${ }_{4}^{+}-\mathrm{N}$ and $\mathrm{NO}_{3}{ }^{-}-\mathrm{N}\left(\mathrm{NH}_{4}{ }^{+}-\mathrm{N} / \mathrm{NO}_{3}{ }^{-}-\mathrm{N}\right.$ ratio), and belowground root biomass $\left(\mathrm{BGB}, \mathrm{kg} \mathrm{m}^{-2}\right)$ in an alpine meadow at three elevations (i.e., $4313 \mathrm{~m}$, $4513 \mathrm{~m}$, and $4693 \mathrm{~m})$ on the Tibetan Plateau. Error bars represent standard error $(n=4)$. MBC and SOC data were obtained from Fu et al. [22].

in grasslands [33, 34]. However, this effect may be often weakened at the three alpine meadow sites because the dung of yak and goat was removed by local residents.

Generally, grazing did not alter the distributions of $R_{s}$, DOC, DON, DOC/DON ratio, $\mathrm{NO}_{3}{ }^{-}-\mathrm{N}, \mathrm{NH}_{4}{ }^{+}-\mathrm{N}$, and BGB along the elevation gradient, which was in line with previous studies $[22,35,36]$.

Soil microbial biomass $\mathrm{N}$ at elevations $4313 \mathrm{~m}$ and $4693 \mathrm{~m}$ and SAN (including $\mathrm{NO}_{3}{ }^{-}-\mathrm{N}$ and $\mathrm{NH}_{4}{ }^{+}-\mathrm{N}$ ) at elevations $4313 \mathrm{~m}$ and $4513 \mathrm{~m}$ under grazing were significantly lower compared with ungrazed soils, while there were no significant differences of SOC, TN, DOC, DON, BGB, and $R_{s}$ between grazed and ungrazed soils (Tables 1 and 2, [22]). This suggests that soil microbial biomass and available $\mathrm{N}$ may respond more rapidly to grazing than SOC, TN, DOC, DON, BGB, and $R_{s}$. The negligible response of $R_{s}$ to grazing was consistent with some previous studies conducted on the Tibetan Plateau (e.g., [15]).

Previous studies showed that BGB increased with increasing TN in alpine grasslands on the Tibetan Plateau 


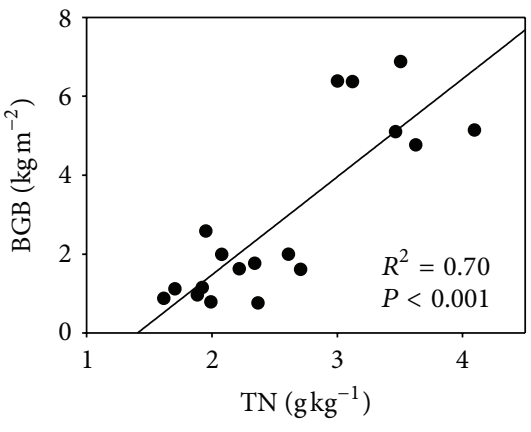

(a)

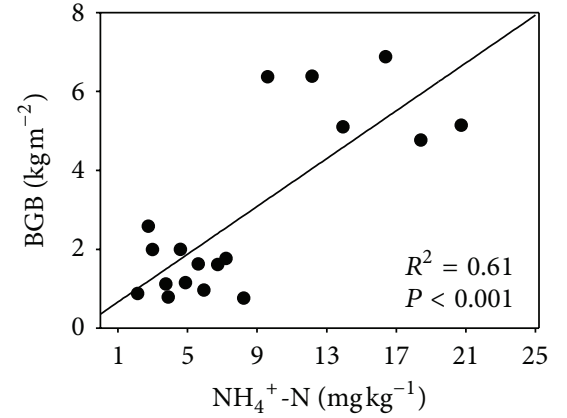

(b)

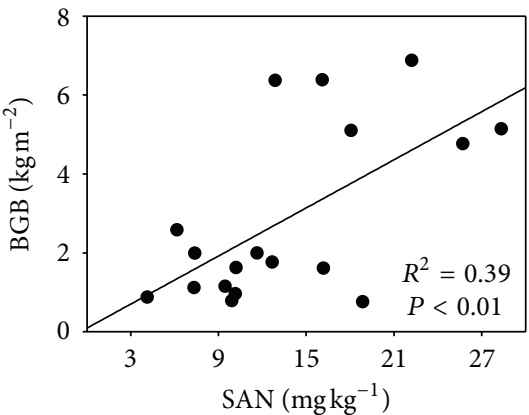

(c)

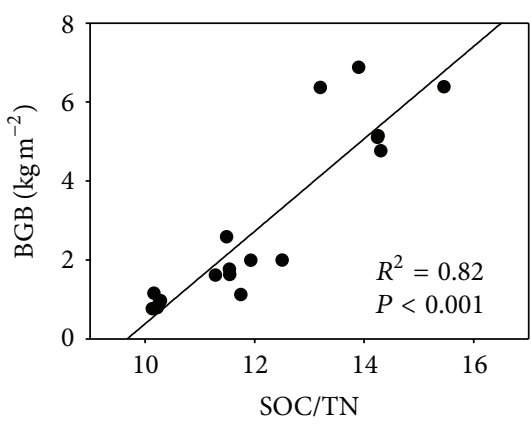

(d)

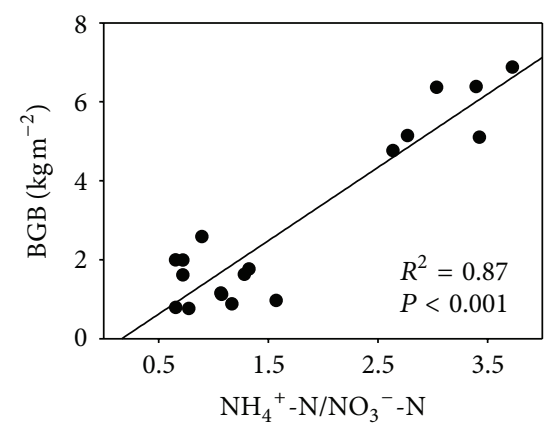

(e)

FIGURE 3: Relationships between belowground root biomass (BGB, $\mathrm{kg} \mathrm{m}^{-2}$ ) and total $\mathrm{N}\left(\mathrm{TN}, \mathrm{g} \mathrm{kg}^{-1}\right)$, ammonium N $\left(\mathrm{NH}_{4}^{+}-\mathrm{N}, \mathrm{mg} \mathrm{kg}^{-1}\right)$, soil available $\mathrm{N}\left(\mathrm{SAN}, \mathrm{mg} \mathrm{kg}^{-1}\right)$, the ratio of SOC and TN (SOC/TN ratio), and the ratio of $\mathrm{NH}_{4}^{+}-\mathrm{N}$ and nitrate $\mathrm{N}^{-}\left(\mathrm{NH}_{4}^{+}-\mathrm{N}^{+} \mathrm{NO}_{3}^{-}-\mathrm{N} \mathrm{ratio}^{-}\right.$, respectively. SOC and TN data were obtained from $\mathrm{Fu}$ et al. [22].

$[36,37]$. Our study confirmed this finding (Figure 3). Besides, BGB increased with increasing $\mathrm{NH}_{4}{ }^{+}-\mathrm{N}, \mathrm{SAN}$, and $\mathrm{NH}_{4}{ }^{+}-$ $\mathrm{N} / \mathrm{NO}_{3}{ }^{-}-\mathrm{N}$ ratio, but not with $\mathrm{NO}_{3}{ }^{-}-\mathrm{N}$. Therefore, the positive relationship between BGB and SAN may be mainly attributed to that between $\mathrm{BGB}$ and $\mathrm{NH}_{4}{ }^{+}-\mathrm{N}$. In addition, the ratio of different soil available $\mathrm{N}$ forms could affect BGB.

Similar to BGB, $R_{s}$ increased with TN, SOC/TN ratio, $\mathrm{NH}_{4}{ }^{+}-\mathrm{N}, \mathrm{SAN}$, and $\mathrm{NH}_{4}{ }^{+}-\mathrm{N} / \mathrm{NO}_{3}{ }^{-}-\mathrm{N}$ ratio, respectively (Figure 4). Meanwhile, $R_{s}$ was positively correlated with BGB (Figure 4). Therefore, the effect of soil $\mathrm{N}$ availability and form on $R_{s}$ was probably associated with the effect of soil $\mathrm{N}$ availability and form on BGB. In addition, the negligible response of $R_{s}$ to grazing may be directly attributed to that of SOC, MBC, DOC, and BGB.

The positive relationships between DOC and SOC, DON and TN, DOC and MBC, DON and MBN, and SAN and MBN (data not shown) were in accordance with previous studies which were made in alpine meadows on the Tibetan Plateau $[22,38]$ and an upland grassland of northern England [39]. Previous studies found that DOC was a good index in reflecting $C$ availability of soil microorganisms [40, 41]. Therefore, the variation of soil microbial biomass along the elevation gradient may be not only associated with that of SOC and TN [22] but also with that of DOC and DON $[6,11,42]$. In other words, soil microbial activity may regulate the balances of soil inorganic and organic $\mathrm{C}$ and $\mathrm{N}$ pools in this alpine meadow.

Many studies have found the positive relationship between $R_{s}$ and $T_{s}$ in various ecosystems $[3,15]$. In contrast, $R_{s}$ increased significantly with increasing elevation, while both soil and air temperatures declined in the current study. In other words, the relationship between $R_{s}$ and $T_{s}$ was negative along the elevation gradient. This implied that other factors (e.g., respiration substrate) probably regulated or confounded the positive relationship between respiration and temperature $[10,25]$. This viewpoint was as confirmed by the positive relationships between $R_{s}$ and $\mathrm{BGB}, \mathrm{SOC}, \mathrm{MBC}$, and DOC (Figure 4).

\section{Conclusions}

In this study, we measured soil respiration under grazed and ungrazed conditions in an alpine meadow along an elevation gradient (4313-4693 $\mathrm{m}$ with approximate $200 \mathrm{~m}$ interval) in Tibet during the period from July to September in 20102011. We found that grazing did not significantly affect soil respiration, which was probably attributed to the insignificant response of respiration substrate (e.g., soil organic $\mathrm{C}$ and belowground root biomass) to grazing. Soil $\mathrm{N}$ availability and the ratio of ammonium to nitrate $\mathrm{N}$ might also influence soil respiration by affecting belowground root growth. 


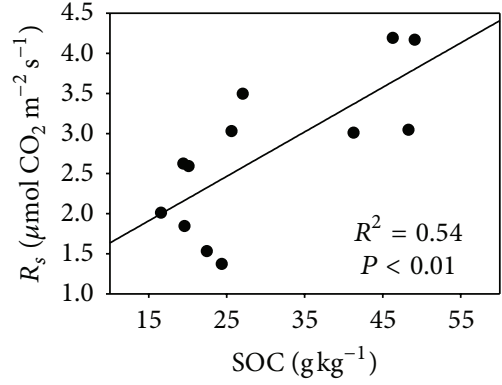

(a)

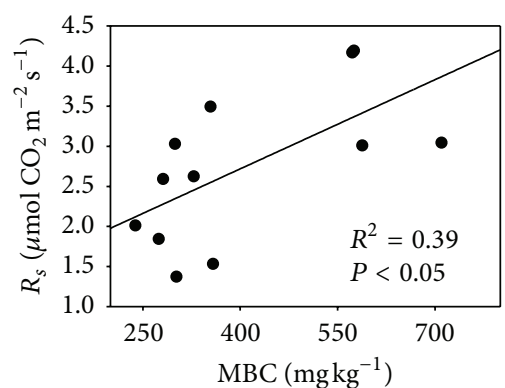

(d)

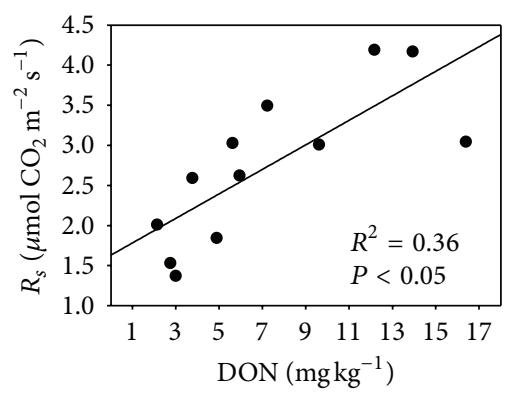

(g)

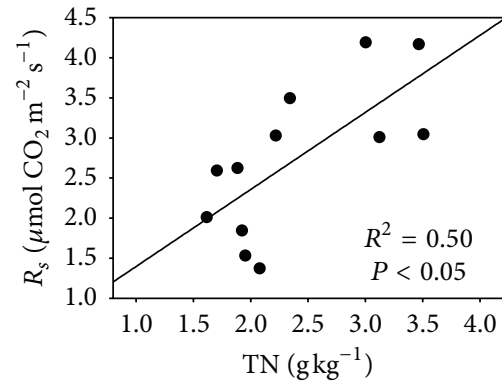

(b)

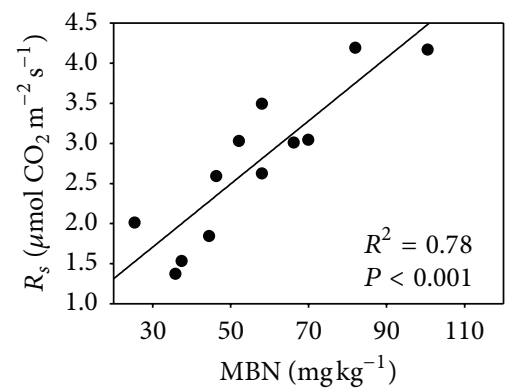

(e)

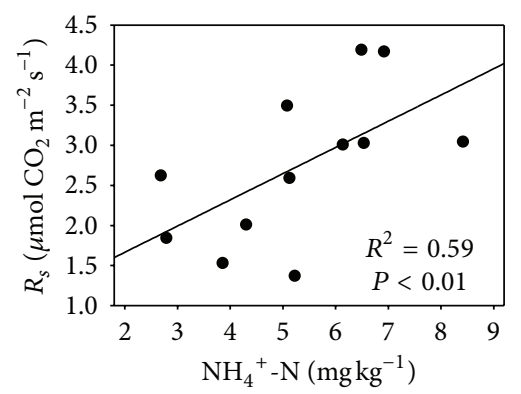

(h)

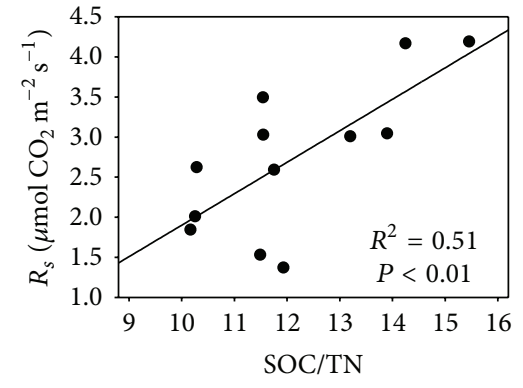

(c)

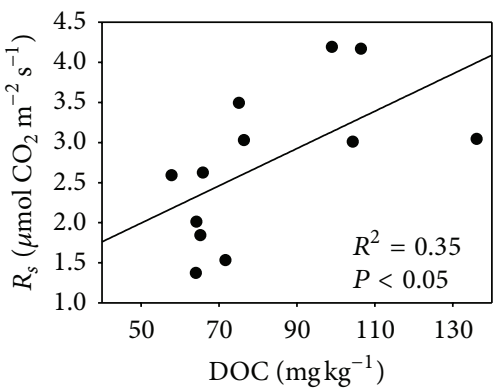

(f)

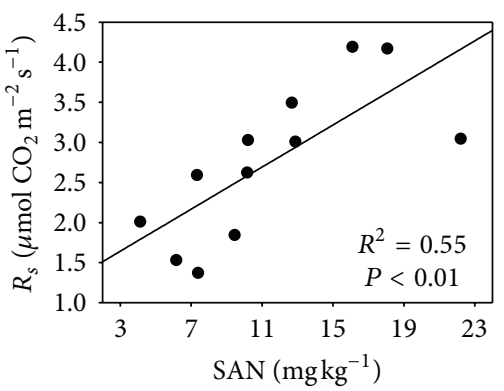

(i)

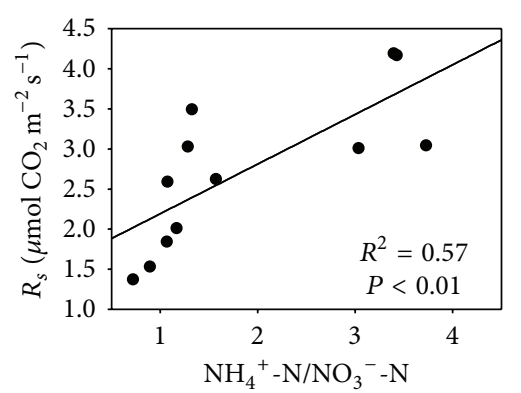

(j)

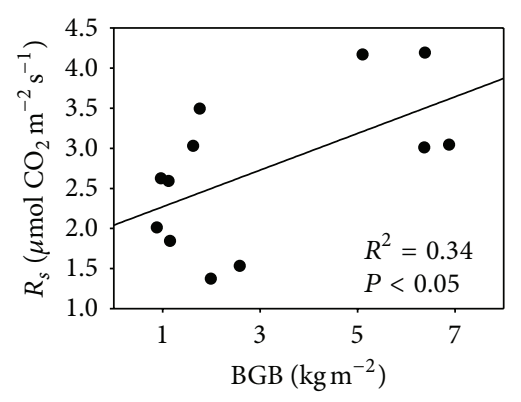

(k)

Figure 4: Relationships between soil respiration $\left(R_{s}, \mu \mathrm{mol} \mathrm{CO} \mathrm{m}^{-2} \mathrm{~s}^{-1}\right)$ measured early in August and September, 2011, and soil organic C (SOC, $\mathrm{g} \mathrm{kg}^{-1}$ ), total $\mathrm{N}$ (TN, $\mathrm{g} \mathrm{kg}^{-1}$ ), the ratio of SOC and TN (SOC/TN ratio), microbial biomass C (MBC, $\mathrm{mg} \mathrm{kg}^{-1}$ ), microbial biomass $\mathrm{N}$ $\left(\mathrm{MBN}, \mathrm{mg} \mathrm{kg}^{-1}\right.$ ), dissolved organic $\mathrm{C}$ (DOC, $\mathrm{mg} \mathrm{kg}^{-1}$ ), dissolved organic $\mathrm{N}$ (DON, $\mathrm{mg} \mathrm{kg}^{-1}$ ), ammonium N $\left(\mathrm{NH}_{4}^{+}-\mathrm{N}^{-} \mathrm{mg} \mathrm{kg}^{-1}\right)$, soil available $\mathrm{N}\left(\mathrm{SAN}, \mathrm{mg} \mathrm{kg}^{-1}\right)$, the ratio of $\mathrm{NH}_{4}{ }^{+}-\mathrm{N}$ and nitrate $\mathrm{N}\left(\mathrm{NH}_{4}{ }^{+}-\mathrm{N} / \mathrm{NO}_{3}{ }^{-}-\mathrm{N}\right.$ ratio), and belowground root biomass (BGB, $\left.\mathrm{kg} \mathrm{m}{ }^{-2}\right)$, respectively. SOC, TN, MBC, and MBN data were obtained from Fu et al. [22].

\section{Conflict of Interests}

The authors declare that there is no conflict of interests regarding the publication of this paper.

\section{Acknowledgments}

This work was funded by the National Natural Science Foundation of China (no. 40771121), National Science and 
Technology Plan Project of China (no. 2011BAC09B03), and the National Basic Research Program of China (nos. 2010CB951704 and 2010CB833502).

\section{References}

[1] J. W. Raich and W. H. Schlesinger, "The global carbon dioxide flux in soil respiration and its relationship to vegetation and climate," Tellus B, vol. 44, no. 2, pp. 81-99, 1992.

[2] L. E. Rustad, J. L. Campbell, G. M. Marion et al., "A metaanalysis of the response of soil respiration, net nitrogen mineralization, and aboveground plant growth to experimental ecosystem warming," Oecologia, vol. 126, no. 4, pp. 543-562, 2001.

[3] Z. Wu, P. Dijkstra, G. W. Koch, J. Peñuelas, and B. A. Hungate, "Responses of terrestrial ecosystems to temperature and precipitation change: a meta-analysis of experimental manipulation," Global Change Biology, vol. 17, no. 2, pp. 927-942, 2011.

[4] J. S. Singh and S. R. Gupta, "Plant decomposition and soil respiration in terrestrial ecosystems," The Botanical Review, vol. 43, no. 4, pp. 449-528, 1977.

[5] L. M. Yan, S. F. Chen, J. H. Huang, and G. H. Lin, "Water regulated effects of photosynthetic substrate supply on soil respiration in a semiarid steppe," Global Change Biology, vol. 17, no. 5, pp. 1990-2001, 2011.

[6] J. Jiang, N. Zonga, M. Song et al., "Responses of ecosystem respiration and its components to fertilization in an alpine meadow on the Tibetan Plateau," European Journal of Soil Biology, vol. 56, pp. 101-106, 2013.

[7] W. X. Liu, Z. Zhang, and S. Q. Wan, "Predominant role of water in regulating soil and microbial respiration and their responses to climate change in a semiarid grassland," Global Change Biology, vol. 15, no. 1, pp. 184-195, 2009.

[8] F. Shi, H. Chen, H. Chen, Y. Wu, and N. Wu, "The combined effects of warming and drying suppress $\mathrm{CO}_{2}$ and $\mathrm{N}_{2} \mathrm{O}$ emission rates in an alpine meadow of the eastern Tibetan Plateau," Ecological Research, vol. 27, pp. 725-733, 2012.

[9] Y. Q. Luo, S. Q. Wan, D. F. Hui, and L. L. Wallace, "Acclimatization of soil respiration to warming in a tall grass prairie," Nature, vol. 413, no. 6856, pp. 622-625, 2001.

[10] S. D. Frey, R. Drijber, H. Smith, and J. Melillo, "Microbial biomass, functional capacity, and community structure after 12 years of soil warming," Soil Biology and Biochemistry, vol. 40, no. 11, pp. 2904-2907, 2008.

[11] J. Iqbal, R. Hu, M. Feng, S. Lin, S. Malghani, and I. M. Ali, "Microbial biomass, and dissolved organic carbon and nitrogen strongly affect soil respiration in different land uses: a case study at Three Gorges Reservoir Area, South China," Agriculture, Ecosystems and Environment, vol. 137, no. 3-4, pp. 294-307, 2010.

[12] G. Fu, X. Z. Zhang, Y. T. Zhou, C. Q. Yu, and Z. X. Shen, "Partitioning sources of ecosystem and soil respiration in an alpine meadow of Tibet Plateau using regression method," Polish Journal of Ecology, vol. 62, pp. 31-38, 2014.

[13] M.-H. Song, J. Jiang, X.-L. Xu, and P.-L. Shi, "Correlation between $\mathrm{CO}_{2}$ efflux and net nitrogen mineralization and its response to external C or $\mathrm{N}$ supply in an alpine meadow soil," Pedosphere, vol. 21, no. 5, pp. 666-675, 2011.

[14] G. Cao, Y. Tang, W. Mo, Y. Wang, Y. Li, and X. Zhao, "Grazing intensity alters soil respiration in an alpine meadow on the Tibetan plateau," Soil Biology and Biochemistry, vol. 36, no. 2, pp. 237-243, 2004.
[15] X. W. Lin, Z. Zhang, S. Q. Wang et al., "Response of ecosystem respiration to warming and grazing during the growing seasons in the alpine meadow on the Tibetan plateau," Agricultural and Forest Meteorology, vol. 151, no. 7, pp. 792-802, 2011.

[16] X. Zhou, S. Q. Wan, and Y. Q. Luo, "Source components and interannual variability of soil $\mathrm{CO}_{2}$ efflux under experimental warming and clipping in a grassland ecosystem," Global Change Biology, vol. 13, no. 4, pp. 761-775, 2007.

[17] M. Bahn, M. Rodeghiero, M. Anderson-Dunn et al., "Soil respiration in European grasslands in relation to climate and assimilate supply," Ecosystems, vol. 11, no. 8, pp. 1352-1367, 2008.

[18] A. B. Frank, M. A. Liebig, and J. D. Hanson, "Soil carbon dioxide fluxes in northern semiarid grasslands," Soil Biology and Biochemistry, vol. 34, no. 9, pp. 1235-1241, 2002.

[19] G. Li and S. Sun, "Plant clipping may cause overestimation of soil respiration in a Tibetan alpine meadow, southwest China," Ecological Research, vol. 26, no. 3, pp. 497-504, 2011.

[20] A. L. Wright, F. M. Hons, and F. M. Rouquette Jr., "Long-term management impacts on soil carbon and nitrogen dynamics of grazed bermudagrass pastures," Soil Biology and Biochemistry, vol. 36, no. 11, pp. 1809-1816, 2004.

[21] G. Shrestha and P. D. Stahl, "Carbon accumulation and storage in semi-arid sagebrush steppe: effects of long-term grazing exclusion," Agriculture, Ecosystems and Environment, vol. 125, no. 1-4, pp. 173-181, 2008.

[22] G. Fu, Z. Shen, X. Zhang, Y. Zhou, and Y. Zhang, "Response of microbial biomass to grazing in an alpine meadow along an elevation gradient on the Tibetan Plateau," European Journal of Soil Biology, vol. 52, pp. 27-29, 2012.

[23] H. Wu, M. Wiesmeier, Q. Yu, M. Steffens, X. Han, and I. Kögel-Knabner, "Labile organic $\mathrm{C}$ and $\mathrm{N}$ mineralization of soil aggregate size classes in semiarid grasslands as affected by grazing management," Biology and Fertility of Soils, vol. 48, no. 3, pp. 305-313, 2012.

[24] X. Xu, S. Niu, R. A. Sherry, X. Zhou, J. Zhou, and Y. Luo, "Interannual variability in responses of belowground net primary productivity (NPP) and NPP partitioning to long-term warming and clipping in a tallgrass prairie," Global Change Biology, vol. 18, no. 5, pp. 1648-1656, 2012.

[25] S. Q. Wan and Y. Q. Luo, "Substrate regulation of soil respiration in a tallgrass prairie: results of a clipping and shading experiment," Global Biogeochemical Cycles, vol. 17, no. 2, pp. 23-1, 2003.

[26] Y. H. Yang, J. Y. Fang, Y. H. Tang et al., "Storage, patterns and controls of soil organic carbon in the Tibetan grasslands," Global Change Biology, vol. 14, no. 7, pp. 1592-1599, 2008.

[27] G. Fu, Z. Shen, X. Zhang, and Y. Zhou, "Response of soil microbial biomass to short-term experimental warming in alpine meadow on the Tibetan Plateau," Applied Soil Ecology, vol. 61, pp. 158-160, 2012.

[28] G. Fu, Z. Shen, X. Zhang et al., "Calibration of MODISbased gross primary production over an alpine meadow on the Tibetan Plateau," Canadian Journal of Remote Sensing, vol. 38, pp. 157-168, 2012.

[29] G. Fu, X. Zhang, Y. Zhang et al., "Experimental warming does not enhance gross primary production and above-ground biomass in the alpine meadow of Tibet," Journal of Applied Remote Sensing, vol. 7, Article ID 073505, 2013.

[30] G. Fu, Z. Shen, X. Zhang, C. Yu, Y. Zhou LI, and P. Yang, "Response of ecosystem respiration to experimental warming and clipping at daily time scale in an alpine meadow of Tibet," Journal of Mountain Science, vol. 10, pp. 455-463, 2013. 
[31] N. Zong, P. Shi, J. Jiang et al., "Responses of ecosystem $\mathrm{CO}_{2}$ fluxes to short-term experimental warming and nitrogen enrichment in an alpine meadow, Northern Tibet Plateau," Scientific World Journal, vol. 2013, Article ID 415318, 11 pages, 2013.

[32] D. L. Jones and V. B. Willett, "Experimental evaluation of methods to quantify dissolved organic nitrogen (DON) and dissolved organic carbon (DOC) in soil," Soil Biology and Biochemistry, vol. 38, no. 5, pp. 991-999, 2006.

[33] D. J. Augustine, S. J. McNaughton, and D. A. Frank, "Feedbacks between soil nutrients and large herbivores in a managed savanna ecosystem," Ecological Applications, vol. 13, no. 5, pp. 1325-1337, 2003.

[34] R. D. Bardgett and D. A. Wardle, "Herbivore-mediated linkages between aboveground and belowground communities," Ecology, vol. 84, no. 9, pp. 2258-2268, 2003.

[35] T. Ohtsuka, M. Hirota, X. Zhang et al., "Soil organic carbon pools in alpine to nival zones along an altitudinal gradient (4400-5300 m) on the Tibetan Plateau," Polar Science, vol. 2, no. 4, pp. 277-285, 2008.

[36] Z. Wang, T. X. Luo, R. C. Li, Y. H. Tang, and M. Y. Du, "Causes for the unimodal pattern of biomass and productivity in alpine grasslands along a large altitudinal gradient in semiarid regions," Journal of Vegetation Science, vol. 24, pp. 189-201, 2013.

[37] Y. H. Yang, J. Y. Fang, C. J. Ji, and W. X. Han, "Above- And belowground biomass allocation in Tibetan grasslands," Journal of Vegetation Science, vol. 20, no. 1, pp. 177-184, 2009.

[38] Y. Rui, S. Wang, Z. Xu et al., "Warming and grazing affect soil labile carbon and nitrogen pools differently in an alpine meadow of the Qinghai-Tibet Plateau in China," Journal of Soils and Sediments, vol. 11, no. 6, pp. 903-914, 2011.

[39] E. Medina-Roldán, J. Paz-Ferreiro, and R. D. Bardgett, “Grazing exclusion affects soil and plant communities, but has no impact on soil carbon storage in an upland grassland," Agriculture, Ecosystems and Environment, vol. 149, pp. 118-123, 2012.

[40] J. N. Boyer and P. M. Groffman, "Bioavailability of water extractable organic carbon fractions in forest and agricultural soil profiles," Soil Biology and Biochemistry, vol. 28, no. 6, pp. 783-790, 1996.

[41] K. Kalbitz, S. Solinger, J.-H. Park, B. Michalzik, and E. Matzner, "Controls on the dynamics dissolved organic matter in soils:a review," Soil Science, vol. 165, no. 4, pp. 277-304, 2000.

[42] M. H. Song, J. Jiang, G. M. Cao, and X. L. Xu, "Effects of temperature, glucose and inorganic nitrogen inputs on carbon mineralization in a Tibetan alpine meadow soil," European Journal of Soil Biology, vol. 46, no. 6, pp. 375-380, 2010. 

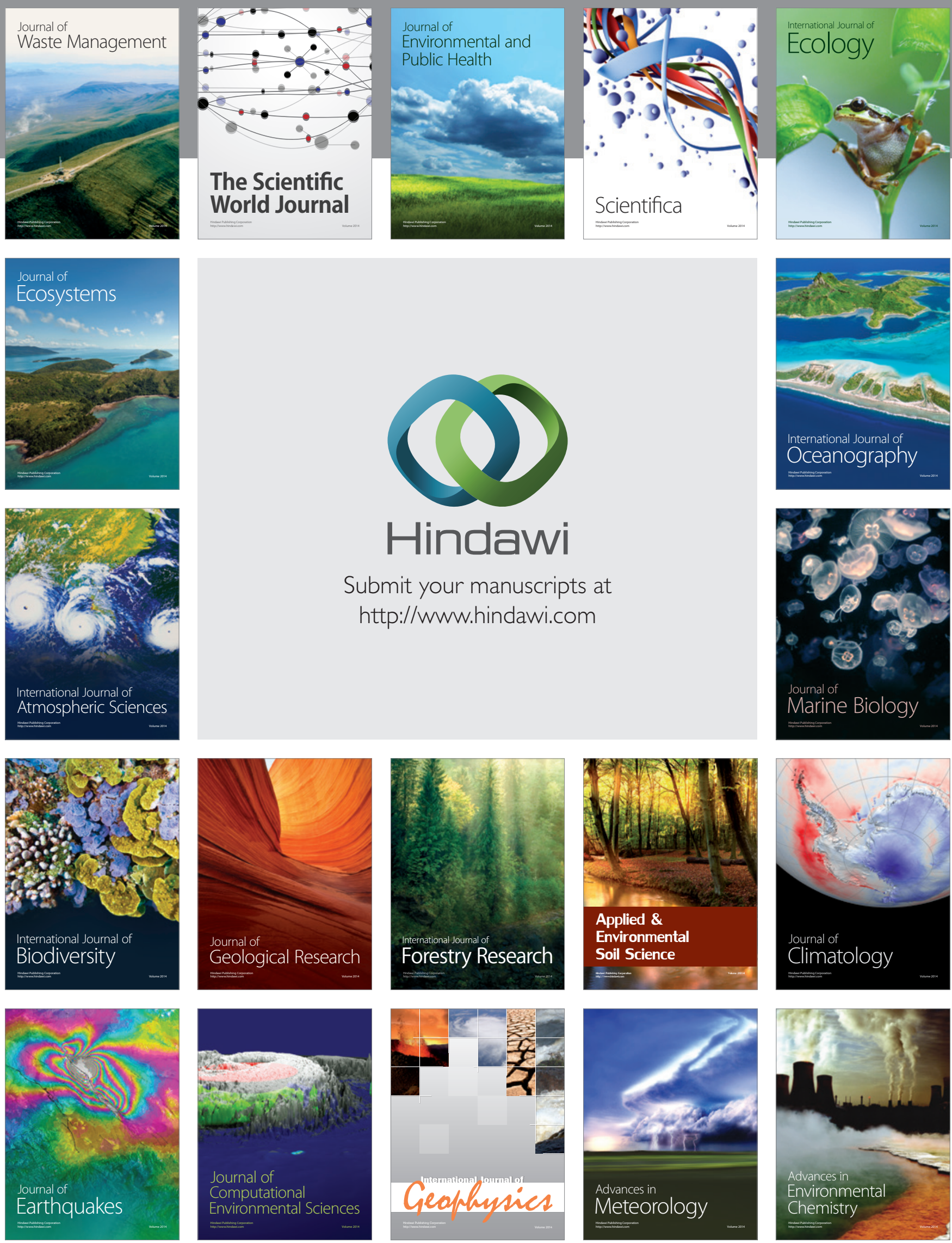